\title{
The Association between Interleukin-6 and Mean Platelet Volume Levels in Central Obesity with or without Non-Alcoholic Fatty Liver Disease
}

\author{
Linda Rotty*, Nelly Tendean ${ }^{* *}$, Nancy Lestari***, Randy Adiwinata*** \\ *Division of Hematology and Medical Oncology, Department of Internal Medicine, \\ Faculty of Medicine, Universitas Sam Ratulangi/Prof dr. R.D. Kandou Hospital, Manado \\ ${ }^{* *}$ Division of Gastroentero-hepatology, Department of Internal Medicine, \\ Faculty of Medicine, Universitas Sam Ratulangi/Prof dr. R.D. Kandou Hospital, Manado \\ ${ }^{* * *}$ Department of Internal Medicine, Faculty of Medicine, Universitas \\ Sam Ratulangi/Prof dr. R.D. Kandou Hospital, Manado
}

\section{Corresponding author:}

Linda Rotty. Division of Hematology and Medical Oncology, Department of Internal Medicine, Prof. dr. R. D. Kandou Hospital. Jl. Raya Tanawangko No.56 Manado Indonesia. Phone: +62-431-7283949. Email: linda_ rotty@yahoo.com

\begin{abstract}
Background: Obesity had become a global problem today. Obesity is a significant risk factor of cardiovascular and other metabolic diseases such as non-alcoholic fatty liver disease (NAFLD). It remains unclear if the increased mean platelet volume (MPV) at the steatosis state is practicable as early detection of the occurrence of fatty liver in individuals with central obesity. This study aims to determine the association of interleukin-6 (IL-6) and MPV levels in central obesity with or without NAFLD.

Method: This study was descriptive-analytic with a cross-sectional approach conducted in Prof. dr. R. D. Kandou Manado general hospital from May to July 2018. Consecutive sampling was performed based on inclusion criteria, then IL-6, MPV, and abdominal ultrasound examinations were performed.

Results: This study included 40 samples of men with central obesity, 28 people (70\%) among them were diagnosed with NAFLD. The Fisher exact test showed an association between NAFLD and an increase in IL-6 ( $p$ $=0.039)$, also between MPV and NAFLD ( $p=0.015)$. Pearson correlation test showed there was no significant correlation between IL-6 and MPV in the NAFLD sample group ( $p=0.084 ; r:-0.332)$ and in the non-NAFLD sample group ( $p=0.564 ; r$ : -0.186).

Conclusion: Elevated MPV and IL-6 values may be used as marker for NAFLD presence among central obesity patients.

Keywords: Interleukin-6, mean platelet volume, non alcoholic fatty liver disease, central obesity

ABSTRAK

Latar belakang: Obesitas merupakan masalah global saat ini. Obesitas merupakan faktor resiko utama dari kejadian kardiovaskular dan penyakit metabolik lainnya seperti perlemakan hati non alkoholik. Hingga saat ini belum diketahui secara pasti apakah peningkatan mean platelet volume (MPV) pada keadaan steatosis dapat digunakan sebagai modalitas deteksi dini adanya perlemakan hati pada pasien dengan obesitas sentral. Penelitian ini bertujuan untuk menentukan hubungan antara kadar interleukin-6 (IL-6) dan MPV ppada pasien dengan obesitas sentral dengan atau tanpa perlemakan hati non alkoholik.
\end{abstract}


Metode: Penelitian ini merupakan penelitian analitik deskriptif dengan pendekatan potong lintang yang dilakukan di Rumah Sakit Umum Pusat Prof dr. Kandou Manado dari bulan Mei hingga Juli 2018. Pengambilan sampel dilakukan secara konsekutif berdasarkan kriteria inklusi, kemudian pemeriksaan kadar IL-6, MPV, dan ultrasonografi abdomen akan dilakukan.

Hasil: Studi ini melibatkan 40 pria dengan obesitas sentral, 28 orang (70\%) diantaranya terdiagnosis mengalami perlemakan hati non alkoholik. Uji Fisher exact menunjukkan hubungan antara perlemakan hati non alkoholik dengan peningkatan kadar IL-6 ( $p=0,039)$, serta antara MPV dan perlemakan hati $(p=0,015)$. Uji korelasi Pearson menunjukkan tidak adanya korelasi antara kadar IL-6 dan MPV pada kelompok dengan perlemakan hati non alkoholik $(p=0,084 ; r:-0,332)$ dan pada kelompok tanpa perlemakan hati non alkoholik $(p=0,0564 ; r:-0,186)$.

Simpulan: Peningkatan kadar MPV dan IL-6 dapat digunakan sebagai penanda adanya perlemakan hati non alkoholik pada pasien dengan obesitas sentral

Kata kunci: Interleukin-6, mean platelet volume, perlemakan hati non alkoholik, obesitas sentral

\section{INTRODUCTION}

Obesity had become a global health problem, according to the World Health Organization (WHO), more than 1.9 billion adults were classified as overweight, and up to 650 million people were obese. ${ }^{1}$ Indonesian National Survey showed a growing number of the adult with obesity from $14.8 \%$ in 2013 to $21.8 \%$ in 2018. ${ }^{2}$ Obesity was linked with a higher number of cardiovascular incident and metabolic disorder such as non-alcoholic fatty liver disease (NAFLD). ${ }^{3,4}$ Study showed up to $50-90 \%$ of obese patients had a simple fatty liver, while non-alcoholic steatohepatitis (NASH) was found in $65-85 \%$ among patients with grade II and grade III obesity. ${ }^{5,6}$

Obesity was associated with the pro-inflammatory state; excess adipose tissue will release proinflammatory factors such as interleukin-6 (IL6 ), tumor necrosis factor-alpha (TNF- $\alpha$ ), other chemokines. ${ }^{7}$ Chronic inflammatory state may lead to atherosclerosis and development of NAFLD. ${ }^{8}$

In recent decades, platelet was found not only responsible in the coagulation process but also, in the process of inflammation. The platelet size was found correlated linearly with the degree of inflammation. Platelet size can be measured using mean platelet volume (MPV), an index for platelet volume, which may reflect the inflammation, function, and platelet activation. ${ }^{9}$ Some studies showed that patients with hepatosteatosis condition, metabolic syndrome, diabetes mellitus, coronary artery disease which usually had chronic low-grade inflammation state, had elevated MPV. ${ }^{10,11}$

Therefore, we would like to assess the relationship between IL-6 and MPV as potential biomarkers in central obese patients with or without NAFLD.
NAFLD commonly present asymptomatically and may progress to steatohepatitis if undetected and treated early. We conducted the study in the young adult population, as many studies had been conducted in the older population and consideration of the importance of early detection of NAFLD in obese patients.

\section{METHOD}

This cross-sectional study was conducted in the Internal Medicine polyclinic of Prof Dr. R.D. Kandou Hospital, Manado, Indonesia, between May-July 2018. The Ethical Committee of the Faculty of Medicine Universitas Sam Ratulangi/Prof R.D. Kandou Hospital approved this study in May 2018 with reference number 069/EC-KEPK/V/2018. The study included male patients who were 18-45 years old with central obesity. Central obesity was defined as waist circumference more than $90 \mathrm{~cm}$. The waist circumference was measured by the research team member at the internal medicine polyclinic. Participants with a history of daily alcohol consumption, more than 30 grams, chronic hepatitis virus infection, diabetes mellitus type 2, impaired renal function, and refused to participate were excluded.

Eligible participants were given the informed consent, interviewed for basic characteristics, and then undergone laboratory testing to measure routine blood count, lipid profile, liver function, renal function, IL-6, and MPV. IL-6 was measured using a reagent kit from R\&D System Inc, with normal reference defined as $\leq$ $1 \mathrm{pg} / \mathrm{mL}$. MPV was measured using the Sysmex XN2000-1-fl R machine. ${ }^{12}$ Elevated MPV level was defined as $>10.2 \mathrm{fL} .{ }^{13}$ After laboratory testing, participants were undergone abdominal ultrasonography (USG) examination by an experienced and board-certified 
radiologist in Prof Dr. R. D. Kandou Hospital to detect the presence of NAFLD. NAFLD was defined as increased echogenicity of the liver compared to the renal cortex, diaphragm, and portal vein.

All data were processed using Statistical Program for Social Sciences (Version 23:Armonk; NY: IBM Corp). The minimum sample size was 38 subjects. Descriptive data on demographics (age), anthropometric (body mass index, waist circumference), clinical characteristics, laboratory value, were presented as a percentage, mean (standard deviation), median (interquartile Range/ IQR) value where appropriate. The normality test of data distribution was tested using the Shapiro-Wilk method. The comparison test for the numerical variable was using the t-independent test, and the categorical value was using Fisher exact test. A correlation test was performed using the Pearson correlation test for normally distributed data and Spearman correlation test for abnormally distributed data. A p-value lower than 0.05 was considered significant.

\section{RESULTS}

Between May and July 2018, a total of 40 subjects met the inclusion criteria and enrolled in this study. The basic characteristics and results of laboratory testing are available in Table 1. The participants in this study had a mean age of 30.1 (SD 5.2) years old, body mass index (BMI) 28.35 (SD 3.59) $\mathrm{kg} / \mathrm{m}^{2}$ (termed as Obesity grade I according to WHO Asia Pacific BMI Classification), and mean waist circumference of 99.08 (SD 8.42$) \mathrm{cm}$. Out of 40 subjects, 28 subjects $(70 \%)$ were diagnosed using USG for having NAFLD.

Among 28 obese participants with NAFLD, there were 25 participants $(89.3 \%$ ) had elevated IL-6 serum level, and among 12 central obese participants with normal liver there were 7 participants had elevated IL-6 serum level. Categorical comparison analysis using Fisher exact method showed elevated IL-6 serum level significantly more common in the NAFLD group compared to normal liver group ([PR] 6; 95\% Confidence interval [CI] 0.993-2.511; $\mathrm{p}=0.039$ ).

The mean IL-6 serum level also found higher in the NAFLD group, 2.27 (SD 0.20) vs. 1.21 (SD 0.07) pg/ $\mathrm{ml}(\mathrm{p}=0.000)$. The mean of MPV value in NAFLD was also found significantly elevated in the NAFLD group, 10.19 (SD 0.82) vs. 9.39 (SD 0,66) fl ( $p=0.005)$, Table 3. However, Pearson correlation test showed there was no significant correlation between IL- 6 and MPV in the NAFLD sample group ( $\mathrm{p}=0.084 ; \mathrm{r}-0.332)$ and in the non-NAFLD sample group $(\mathrm{p}=0.564 ; \mathrm{r}-0,186)$.

MPV laboratory testing showed an elevation in 14 obese patients with NAFLD and 11 patients without NAFLD. This finding was statistically significant using the Fischer exact test (PR 6; 95\% CI 0.886-40.629; p $=0.015)$, Table 4 .

Table 1. Baseline sample characteristics

\begin{tabular}{|c|c|c|c|c|}
\hline & $\mathrm{n}=\mathbf{4 0}$ & NAFLD Group (n= 28) & Non NAFLD Group $(n=12)$ & $p$ \\
\hline Age (years old), mean (SD ) & 30.1 (SD 5.2) & 30.0 (SD 0.99) & 30.33 (SD 1.49) & 0.854 \\
\hline Body mass index $\left(\mathrm{kg} / \mathrm{m}^{2}\right)$, mean (SD) & 28.35 (SD 3.59) & 27.27 (SD 1.49) & 24.78 (SD 2.33) & 0.369 \\
\hline Waist circumference $\mathrm{cm}$, mean(SD) & 99.08 (SD 8.42) & 100.60 (SD 1.63) & 95.50 (SD 1.98) & 0.078 \\
\hline Fatty liver, n (\%) & $28(70)$ & $28(100)$ & $0(0)$ & \\
\hline Hemoglobin (g/dL), mean(SD) & $15.52(\mathrm{SD} 0.81)$ & 14.5 (SD 0.56) & 15.5 (SD 0.26) & 0.361 \\
\hline Hematocrite(\%),mean(SD) & $45.72(\mathrm{SD} 1.76)$ & $41.19(\mathrm{SD} 2.44)$ & $35.50(\mathrm{SD} 5.43)$ & 0.275 \\
\hline Platelet $(/ \mu \mathrm{L})$, mean $(\mathrm{SD})$ & 304,350 (SD 53,160.40) & $297,142.86(S D 9746.21)$ & 321166.67 (SD 15943.95) & 0.194 \\
\hline AST (U/L), mean(SD) & $26.38(\mathrm{SD} 14.17)$ & $28.5(\mathrm{SD} 3.02)$ & $21.42(\mathrm{SD} 2.01)$ & 0.150 \\
\hline ALT (U/L), mean(SD) & 38.80 (SD 34.58) & $41.61(\mathrm{SD} 7.48)$ & 32.25 (SD 5.26) & 0.440 \\
\hline $\begin{array}{l}\text { Fasting blood glucose (gr/dL), } \\
\text { mean(SD) }\end{array}$ & 85.05 (SD 8.46) & 83.96 (SD 1.63) & 87.58 (SD 2.25) & 0.219 \\
\hline Total cholesterol (mg/dL), mean(SD) & 209.00 (SD 34.34) & 207.29 (SD 6.58) & 213.00 (SD 9.91) & 0.636 \\
\hline $\begin{array}{l}\text { Low density lipoprotein (mg/dL), } \\
\text { mean(SD) }\end{array}$ & 140.78 (SD 3.54) & 139.25 (SD 5.89) & 144.33 (SD 9.65) & 0.646 \\
\hline $\begin{array}{l}\text { High density lipoprotein }(\mathrm{mg} / \mathrm{dL}) \text {, } \\
\text { mean(SD) }\end{array}$ & 43.93 (SD 7.67) & 43.43 (SD 1.49) & 45.1 (SD 2.13) & 0.539 \\
\hline Triglycerides (mg/dL), mean(SD) & 119.43 (SD 50.84) & $120.0($ SD 10.27) & $118.08(\mathrm{SD} 12.64)$ & 0.915 \\
\hline
\end{tabular}

${ }^{*}$ Comparison between NAFLD and the non-NAFLD group was made using t-independent test

Table 2. Distribution of IL-6 among the subjects

\begin{tabular}{llll}
\hline Variable & Elevated IL-6, $\mathbf{n}(\%)$ & Normal IL-16, $\mathbf{n}(\%)$ & $\mathbf{p}$ \\
\hline NAFLD & $25(89.3)$ & $3(10.7)$ & 0.039 \\
Normal liver & $7(58.3)$ & $5(41,7)$ & \\
\hline \multicolumn{2}{l}{ Table 3. Comparison of IL-6 } & and MPV among the subjects & \\
\hline Variable & NAFLD (n=28) & Normal liver (n = 12) & $\mathbf{p}$ \\
\hline IL-6 (pg/mL) mean (SD) & $2.27($ SD 0.20) & $1.21(S D ~ 0.07)$ & 0.000 \\
MPV (fL) mean (SD) & $10.19(S D ~ 0.82)$ & $9.39(S D ~ 0.66)$ & 0.005 \\
\hline
\end{tabular}


Table 4. Distribution of MPV among the subjects

\begin{tabular}{llll}
\hline Variable & $\begin{array}{l}\text { Elevated MPV, } \\
\mathbf{n}(\%)\end{array}$ & $\begin{array}{l}\text { Normal MPV, } \\
\mathbf{n}(\%)\end{array}$ & $\mathbf{p}$ \\
\hline NAFLD & $14(50)$ & $14(50)$ & 0.015 \\
Normal liver & $1(4.5)$ & $11(91,7)$ & \\
\hline
\end{tabular}

\section{DISCUSSION}

Obesity was strongly associated with the development of metabolic syndrome and comorbidities such as NAFLD. The study included 40 samples of men with central obesity, in which 28 people $(70 \%)$ were having NAFLD. These results were in line with the study by Vernon et al. that fatty liver was found in $10-15 \%$ of normal-weight people and reached $70 \%$ in obese subjects. ${ }^{14}$ Stronger association was found between central obesity and NAFLD; visceral fat is actively metabolized and secretes several hormones that cause inflammation. ${ }^{15,16}$ The risk for having NAFLD was doubled among patients with central obesity. ${ }^{17}$ Adipose tissue in central obesity can increase circulated free fatty acids and plays a central role in a part of the first hit process of NAFLD pathogenesis. ${ }^{6,18}$ Free fatty acids will induce oxidation and esterification of fat, which results in increased oxidized free fatty acids induced by ROS, which triggers the second hit. Accumulated fat in the liver, along with intracellular stress processes, will activate transcription and release of proinflammatory cytokines, such as IL-6. Lowgrade inflammation state was found due to increased proinflammatory cytokine levels and reduced antiinflammatory factors. ${ }^{6,19-21}$ This study obtained an average IL-6 of 1.95 (SD 1.03) pg/mL. This average increase in IL-6 is in accordance with the results of the study by Schober et al. $1 \mathrm{pg} / \mathrm{Ml}$ in the control group and about 2 to 4 times higher in obesity. ${ }^{22}$

The role of IL-6 in NAFLD pathogenesis is very complex and still unclear. In the early phase, IL-6 may serve as hepatoprotector that can reduce oxidative stress and prevent mitochondrial dysfunction. However, prolonged low-level inflammation due to persistent elevated IL-6 level may cause liver injury and induce insulin resistance. ${ }^{23}$ The results of this study obtained a relationship between NAFLD with elevated serum IL-6 levels. The results of this study are consistent with research by Jarrar et al. that showed IL-6 level was elevated among NAFLD patients compared to the obese patient without NAFLD. ${ }^{24}$ Further study by Wieckowska et al. IL-6 showed that IL-6 is positively correlated with the severity degree of NAFLD, which IL-6 is higher with NASH compared to simple steatosis or normal biopsy. ${ }^{25}$ Research by Coulon et al in 92 study subjects consisted of 30 obese patients with steatosis, 32 patients with NASH, and in 30 controls, IL-6 levels were significantly increased in the simple steatosis group (mean 2,863 vs. $1,224 \mathrm{pg} / \mathrm{mL}$; $\mathrm{p}<0.001$ ) and NASH patients (mean $3.65 \mathrm{vs} .3 .15 \mathrm{pg}$ / $\mathrm{mL} ; \mathrm{p}<0.001) .{ }^{26}$

Interleukin-6 can cause low-grade inflammation in hepatosteatosis, induce thrombopoiesis, and cause platelet activation, which in this study was represented by MPV. Higher MPV means an increase in platelet volume, more active metabolic ability, and enzymatic reaction. Mean platelet volume is used to measure platelet volume and is also a marker of platelet activity. Platelet function is influenced by the size, density, age, and previous hemostatic interactions. Reactive platelets, which are larger platelets, have more granules and adhesion receptors, which can result in decreased bleeding time and increased platelet activation. ${ }^{27,28} \mathrm{We}$ found samples with NAFLD had increased MPV ( $\mathrm{p}$ $=0.015)$. The results of this study are in accordance with a research by Shin et al. in Korea in 628 obese patients. ${ }^{28}$ Alempijevic et al. studied in 98 NAFLD patients and 60 controls, and found a significant difference in mean MPV values between NAFLD patients and controls (mean 9.1 [SD 1.3] vs. 7.6 [SD $1.1] ; \mathrm{p}<0.01) .{ }^{29}$ Ozhan et al. studied that patients with NAFLD had higher MPV compared to patients without NAFLD (mean 10.43 [SD 1.14] vs. 9.09 [SD 1.25]). ${ }^{30}$ In the study by Eldin et al. in 23 NAFLD patients and 11 controls, it was found that MPV levels increased significantly in NAFLD (mean 11, 37 [SD 0.94] vs. 9.9 [SD 1.11], p 0,000). ${ }^{31}$ Madan et al. conducted a metaanalysis study showing that MPV was significantly higher in patients with NAFLD, indicating an increase in platelet activity in these patients. ${ }^{32}$

The exact mechanism of increased platelet volume in NAFLD is not yet clearly understood. The most likely explanation is the response to inflammatory mediators expressed with changes in platelets size. ${ }^{10.11}$ Another mechanism is related to the presence of insulin resistance caused by NAFLD, which will increase the MPV value. The study by Li et al. involving 600 patients, the results showed an increase in insulin resistance in NAFLD. Insulin resistance was related to the elevation of MPV. ${ }^{33}$

However, in this study, no correlation was found between IL-6 and MPV both in the NAFLD group and in the non-NAFLD sample group. There were also several studies that found elevated levels of IL6 , but the MPV value was still normal. This might be due to the influence of IL-6 gene polymorphism. IL-6 gene polymorphisms have been reported to influence the results of studies where certain alleles 
have an influence on MPV while other IL-6 alleles less affect megakaryocyte maturation. Real et al. found in their study that subjects with homozygous $\mathrm{C}$ alleles (genotype CC) showed lower IL-6 levels compared to subjects with GC or GG alleles. ${ }^{34}$ Other possible explanations may be related to degree of physical activity. Physical activity can reduce IL-6 levels, but if the intensity is excessive, especially in non-aerobic exercise, it can increase the MPV value. Low physical activity is associated with an increase in IL-6 levels at rest. ${ }^{35,36}$ Physical exercise will reduce the accumulation of mRNA-IL6 buildup through the mechanism of contraction in skeletal muscle. It has contributed to the non-meaningful relationship between IL-6 and MPV levels. ${ }^{37}$ However, we have no data regarding the physical activity degree for our subjects.

Another thing that influences the formation of MPV is other cytokines. Platelet size is determined at the time of megakaryocyte production, which is mediated by cytokines such as IL-3 and IL-6. Interleukin-3 also increases cellularity and the bone marrow progenitor cell cycle. Interleukin-3, together with G-CSF, has the potential to stimulate various hematopoietic cells into myeloid progenitor cells, including triggering the proliferation of various myeloid cells, such as erythrocytes, megakaryocytes, granulocytes, monocytes, and dendritic cells. Interleukin-3 plays a role in various cellular activities, such as cell development, cell differentiation and apoptosis. ${ }^{38,39}$

There are limitations to the present study. The first one is the use of ethylenediaminetetraacetic acid (EDTA) as an anticoagulant, which may cause platelet swelling. The second limitation is that our analysis is based on a simple baseline determination that may not reflect the patient's inflammatory status for a long time. We also did not examine the levels of other proinflammatory cytokines that might have played a role in this study. A third limitation, several factors can influence IL-6 levels that need to be considered and analyzed further, such as physical and genetic activity.

\section{CONCLUSION}

Most of the obese patients had NAFLD. There is a relationship between non-alcoholic fatty liver with elevated IL- 6 and MPV levels in central obesity patients; therefore, IL-6 and MPV may become the markers for NAFLD presence. However, there is no correlation was found between IL-6 levels and MPV values in central obesity in both the NAFLD and nonNAFLD groups.

\section{REFERENCES}

1. World Health Organization (WHO). World Health Organization Fact Sheet: Obesity and Overweight [serial online]. Geneva: WHO [cited 2020 January 30]. Available from: https:// www.who.int/news-room/fact-sheets/detail/obesity-andoverweight.

2. Badan Penelitian dan Pengembangan Kesehatan Kementerian Kesehatan Republik Indonesia. Riset Kesehatan Dasar. Jakarta: Litbangkes. 2018.

3. Di Angelantonio E, Bhupathiraju S, Wormser D, Gao P, Kaptoge S, de Gonzalez AB, et al. Body-mass index and allcause mortality: individual-participant-data meta-analysis of 239 prospective studies in four continents. The Lancet 2016;388:776-86.

4. Younossi ZM, Koenig AB, Abdelatif D, Fazel Y, Henry L, Wymer M. Global epidemiology of nonalcoholic fatty liver disease - Meta analytic assessment of prevalence, incidence, and outcomes. Hepatology 2016;64:73-84.

5. Demir M, Lang S, Steffen HM. Nonalcoholic fatty liver disease - current status and future directions. J Dig Dis 2015;16:541-57.

6. Divella R, Mazzocca A, Daniele A, Sabba C, Paradiso A. Obesity, nonalcoholic fatty liver disease and adipocytokines network in promotion of cancer. Int J Biol Sci 2019;15:610-6.

7. Das SK, Balakrishnan V. Role of Cytokines in the Pathogenesis of Non-Alcoholic Fatty Liver Disease. Ind J Clin Biochem 2011;26:202-9

8. Turner MD, Nedjai B, Hurst T, Pennington DJ. Cytokines and chemokines: at the crossroads of cell signalling and inflammatory disease. Biochimica et Biophysica Acta (BBA)Molecular Cell Research 2014;1843:2563-82.

9. Zsóri KS, Mahalek M, Mokarrami MA, Csiki Z, Shemirani AH. Preanalytical factors affecting the mean platelet volume: a review. Global J Hematol Blood Transfus 2016;3:18-22.

10. 10. Gasparyan AY, Ayvazyan L, Mikhailidis DP, Kitas GD. Mean platelet volume: a link between thrombosis and inflammation? Current pharmaceutical design 2011;17:47-58.

11. Alvarez L, Cipher D, Weideman R, Brown G. Mean platelet volumes in non-alcoholic fatty liver disease (NAFLD): relationship to cardiovascular events. Gastroenterol Hepatol Open Access 2016;5:1-5.

12. R\&D Systems. Human IL-6 Quantikine ELISA Kit [serial online] 2020 [cited 2020 July 19]. Available from: https:// www.rndsystems.com/products/human-il-6-quantikine-elisakit_d6050\#: : text=Normal\%20human $\% 20$ circulating $\% 20$ IL\%2D6,and\%20large\%20elevations\%20after\%20surgery.

13. Keohane E, Smith L, Walenga J. Rodak's Hematology: Clinical principles and applications. 2015. Elsevier. $5^{\text {th }}$ ed.p.249.

14. Vernon G, Baranova A, Younossi ZM. Systemic review: the epidemiology and natural history of non-alcoholic steatohepatitis in adults. Aliment Pharmacol Ther 2011;34:274-85.

15. Pedersen SD. Metabolic complications of obesity. Clinical Endocrinology \& Metabolism Journal 2013;27:179-93.

16. 16. Fotbolcu H, Zorlu E. Nonalcoholic fatty liver disease as a multi-systemic disease. World J Gastroenterol 2016;22:407990.

17. Fan JG, Saibara T, Chitturi S, Kim BI, Sung JJY, Chutaputti A. What are the risk factors and settings for non-alcoholic fatty liver disease in Asia-Pacific? J Gastroenterol Hepatol 2007;22:794-800. 
18. Buzzetti E, Pinzani M, Tsochatzis EA. The multiple-hit pathogenesis of non-alcoholic fatty liver disease (NAFLD). Metabolism 2016;65:1038-48.

19. Polyzos SA, Mantzoros CS. Nonalcoholic fatty liver disease: from pathogenesis to emerging treatment. Metabolism Clinical and Experimental 2016;1007-16.

20. Haas JT, Francque S, Staels B. Pathophysiology and mechanisms of nonalcoholic fatty liver disease. Annual review of physiology 2016;78:181-205.

21. Asrih M, Jornayvaz FR. Inflammation as a potential link between non-alcoholic fatty liver disease and insulin resistance. Journal of Endocrinology 2013;218:25-36.

22. Schober F, Neumeier M, Weigert J, Wurm S, Wanninger J, Schaffler A, et al. Low molecular weight adiponectin negatively correlates with the waist circumference and monocytic IL-6 release. Biochem Biophys Res Commun 2007;361:968-73.

23. Braunersrither V, Viviani GL, Mach F, Montecucco F. Role of cytokines and chemokines in non-alcoholic fatty liver disease. World J Gastroenterol 2012;18:727-35.

24. Jarrar MH, Baranova A, Collantes R, Ranard B, Stepanova M, Bennett $\mathrm{C}$, et al. Adipokines and cytokines in non-alcoholic fatty liver disease. Aliment Pharmacol Ther 2008;27:412-21.

25. Wieckowska A, Papouchado BG, Li Z, Lopez R, Zein NN, Feldstein AE. Increased hepatic and circulating interleukin-6 levels in human nonalcoholic steatohepatitis. Am J Gastroenterol 2008;103:1372-9.

26. Coulon S, Francque S, Colle I, Verrijken A, Blomme B, Heindryckx F, et al. Evaluation of inflammatory and angiogenic factors in patients with non-alcoholic fatty liver disease. Cytokine 2012;59:442-9.

27. Madan SA, John F, Pitchumoni CS. Nonalcoholic fatty liver disease and mean platelet volume: a systemic review and meta-analysis. J Clin Gastroenterol 2016;50:69-74.

28. Shin WY, Jung DH, Shim JY, Lee HR. The association between non-alcoholic hepatic steatosis and mean platelet volume in an obese Korean population. Platelets 2011;22:x.

29. Alempijevic T, Lalosevic M, Dumic I, Jocic N, Markovic AP, Dragasevic S et al. Diagnostic accuracy of platelet count and platelet indices in noninvasive assessment of fibrosis in nonalcoholic fatty liver disease patients. Canadian J Gastroenterol Hepatol 2017;2017:6070135.

30. Ozhan H, Aydin M, Yazici M, Yazgan O, Basar C, Gungor A, et al. Mean platelet volume in patients with non-alcoholic fatty liver disease. Platelets 2010;21:29-32.

31. Shehab-Eldin W, Efat A, Shehab-Eldeen S, Essa A, Abdou MA, Omar H, et al. Mean platelet volume as a novel surrogate marker for early Non-Alcoholic Fatty Liver Disease. Life Sci J 2015;12:200-5.

32. Madan SA, John F, Pitchumoni CS. Nonalcoholic fatty liver disease and mean platelet volume: a systemic review and meta-analysis. J Clin Gastroenterol 2016;50:69-74.

33. Li M, Zhang S, Wu Y, Ye J, Cao X, Lie J, et al. Prevalence of insulin resistance in subjects with nonalcoholic fatty liver disease and its predictors in a Chinese population. Dig Dis Sci 2015;60:2170-6.

34. Fernandez-Real JM, Vendrell J, Richart C, Guiterrez C, Ricart W. Platelet count and interleukin 6 Gene polymorphism in healthy subjects. BMC Medical Genetics 2001;2:x.

35. Sadeghi E, Omidi M, Yousefi M, Rahimi A, Branch I. The impact of one aerobic and resistance training session on some hematological responses of non-athlete woman. Indian Journal of Fundamental and Applied Life Sciences 2014;4:2667-72.
36. Fischer C. Interleukin- 6 in acute exercise and training: what is the biological relevance? Exerc Immunol Rev 2006;12:6-33.

37. FitzGerald L, Macey MP, Brecht ML. Pathways to interleukin-6 in healthy males and serious leisure male athletes: physical activity, body composition and age. PLoS ONE 2012;7: e40513.

38. Hoffbrand AV, Moss PA. In: Hoffbrand's Essential Haematology. Platelets blood coagulation and haemostasis. $7^{\text {th }}$ ed. John Wiley \& Sons Ltd.2016.p.264-77.

39. Geddis AE. Megakaryocytes. In: Greer JP, Arber DA, Glader B, List AF, Means RT, Paraskevas F, et al. Wintrobe's Clinical Hematology.13 ${ }^{\text {th }}$ ed. Lippincott Williams \& Wilkins 2014. p.371-88. 